\title{
Defining Health Mavens On Demographic Characteristics: A Pilot Study In Istanbul
}

\author{
Emrah Cengiz, Prof. Dr. \\ Dr. Irfan Akyuz, Dr. \\ Dr. Gultuvin Gur Omay, Dr. \\ Merve Bosat, PhD Candidate \\ Istanbul University, Turkey
}

doi: 10.19044/esj.2016.v12n13p93 URL:http://dx.doi.org/10.19044/esj.2016.v12n13p93

\begin{abstract}
Market mavens are people who have general information about the market and share this information with other consumers even though they do not use the product or service. Market mavens are consumers who actively communicate with the market and every level of the product life cycle. In this study, it is aimed to define the demographic characteristics of health mavens who are a special type of market mavens. In the scope of the study, consumers that are aged 18 and above are included. 387 questionnaire forms are evaluated. People participated in the study are \%52,4 female, \%47,6 male; \%49,8 single, \%50,2 married and \%35,9 18-28 aged, \%26,1 29-39 aged, \%22 40-50 aged and \%16 51 and above. Employed people form $\% 78,6$, students $\% 13,1$, unemployed \%8,3 of the sample. Lower income group $\% 22,2$, middle income group $\% 60,5$ and high income group $\% 17,3$ are classified on monthly basis. Besides, 387 people of the sample are high level $\% 48,5$, middle level \%25,1 and low level \%26,4 are health mavens. According to the correlation analysis, age, education and marital status are determining characteristics of health mavens. But, there is no meaningful relationship between gender, occupation and income levels of participants' health maven levels statistically.
\end{abstract}

Keywords: Market Maven, Health Maven, W.O.M.M

\section{Introduction}

Word of mouth marketing is an important source of information that affects buyer attitudes and buying behavior and when compared to other promotional activities is more cost effective For this reason, by helping to distribute information in the market is beginning to be evaluated as a source of communication because it also reinforces the recognition level of the 
firms in the service sector. In marketing literature, the three groups that effect the consumers are defined. These are; "Innovators", "Opinion Leaders" and "Market Mavens” which are defined by Feick\& Price (1987). Although people in these three groups have tendency to share information and experience with consumers; each group have different traits and attitudes. (Goldsmith vd., 2003).

Opinion leaders are people who have extensive information about on specific product categories and share this information regularly and give advice. Innovators come to the foreground by their information on new products. They mostly share information through dialogues on the products. Innovators, are easily adapted to innovation therefore; they are referred to early adapters. (Slama and Williams, 1990; Brancaleone and Gountas, 2007). But market mavens have more information about the marketplace and share this information with consumer groups. Market mavens possess information about the marketplace and provide this information to consumers even though they do not use or buy the product therefore they take part in active communication and have interest in every level of the product life cycle. Feick and Price, 1987; Fitzmaurice, 2011).

Market mavens differ from other special consumer groups with the characteristics stated above. In literature, there is no consensus on market mavens' specific characteristics but there are literature more on innovators and opinion leaders. Especially in literature, there is a little research on health mavens in health sector. Considering national research, word of mouth marketing in health sector (Y1lmaz, 2011; Öz\&Uyar, 2014; Uzunal\&Uydac1, 2012.) and market mavens (Avcilar, 2005; Yener, 2012\&2013; Unal\&Gorgun, 2014; Yolaç \&Akyuz, 2014) can be seen in the literature. These research are limited when compared to international literature. (Feick\&Price, 1987; Slama\&Williams, 1990; Goldsmith et.al., 2003; Goodey\&East, 2008, Barnes\&Pressey, 2012; Hongwei, 2013). In national literature, there is no study that takes market mavens on health sector basis. On the other hand in international literature; only one study mentions "health mavens”. (Boster et al., 2011) In this study, health mavens are referred to as individuals who have extensive information on "healthy living and health", have tendency to share this information with other individuals and often recognized as experts concerning health matters” Afore mentioned above, in this study demographic characteristics of health mavens are tried to be determined. In this respect, this study could provide a basis for studies that include psychological and behavioral dimensions of the health mavens. The plan of the research is as follows; the literature review, the aim of the study and the scale used, sample of the study , findings and ends with a conclusion where findings are discussed and analyzed. 


\section{Literature Review}

Market mavens are less analyzed group when compared to innovators and opinion leaders. Research carried out is to find the demographic characteristics and behavior of the market mavens. (Clark ve Goldsmith, 2005). In the first study, done by Feick\&Price (1987), it is found out that there is no meaningful difference between market mavens and non-mavens concerning age, income, members of the household, and children under 18. Besides, it is found out that women have more tendency to be market mavens compared to men and market mavens have low education levels. After this pioneer study, succeeding studies also analyzed the psychological and behavioral traits of the market mavens. They are shown in Table 1 below.

Table 1: International Research on Market Mavens

\begin{tabular}{|c|c|c|c|c|c|}
\hline Author(s) & Year & $\begin{array}{c}\text { Samp } \\
\text { le } \\
\text { Size }\end{array}$ & $\begin{array}{c}\text { Countr } \\
\mathrm{y}\end{array}$ & Dimension & Findings \\
\hline $\begin{array}{c}\text { Slama\& } \\
\text { Williams }\end{array}$ & 1990 & 612 & USA & $\begin{array}{c}\text { Demographi } \\
\text { c }\end{array}$ & $\begin{array}{l}\text { Gender difference has an } \\
\text { effect on the } \\
\text { service/product category, } \\
\text { Obtaining and sharing } \\
\text { information process is } \\
\text { different between market } \\
\text { mavens and nonmavens. }\end{array}$ \\
\hline $\begin{array}{l}\text { Williams } \\
\text { \& Slama }\end{array}$ & 1995 & 612 & USA & $\begin{array}{c}\text { Demographi } \\
\text { c }\end{array}$ & $\begin{array}{c}\text { There is a difference of } \\
\text { service/product } \\
\text { information and brand } \\
\text { evaluation based on } \\
\text { gender. } \\
\text { There is no difference due } \\
\text { to the demographic } \\
\text { characteristics. }\end{array}$ \\
\hline $\begin{array}{c}\text { Abratt, } \\
\text { Nel \& } \\
\text { Nezer }\end{array}$ & 1995 & 621 & $\begin{array}{l}\text { South } \\
\text { Africa }\end{array}$ & $\begin{array}{c}\text { Demographi } \\
\text { C }\end{array}$ & $\begin{array}{l}\text { Market mavens have } \\
\text { impact on people and they } \\
\text { are important for the } \\
\text { retailers. } \\
\text { There is no difference due } \\
\text { to the demographic } \\
\text { characteristics. }\end{array}$ \\
\hline $\begin{array}{l}\text { Chelminsk } \\
\text { i \&Couter }\end{array}$ & 2002 & 229 & Poland & $\begin{array}{c}\text { Demographi } \\
\text { c }\end{array}$ & $\begin{array}{c}\text { There are similar } \\
\text { characteristics between } \\
\text { those living in Poland and } \\
\text { those living in the USA. } \\
\text { Market mavens are } \\
\text { younger. } \\
\text { There is no difference } \\
\text { according to other } \\
\text { characteristics. }\end{array}$ \\
\hline $\begin{array}{l}\text { Geissler\& } \\
\text { Edison }\end{array}$ & 2005 & 565 & USA & Psychologic & $\begin{array}{c}\text { There is a difference } \\
\text { between market mavens } \\
\text { and nonmavens due to } \\
\text { Psychological indicators. } \\
\text { There is a positive } \\
\text { correalition between }\end{array}$ \\
\hline
\end{tabular}




\begin{tabular}{|c|c|c|c|c|c|}
\hline & & & & & $\begin{array}{l}\text { technology and market } \\
\text { mavenism. }\end{array}$ \\
\hline $\begin{array}{l}\text { Clark\& } \\
\text { Goldsmith }\end{array}$ & 2005 & 644 & USA & Psychologic & $\begin{array}{l}\text { Psychological foundations } \\
\text { and individual networking } \\
\text { are important to } \\
\text { understand the market } \\
\text { mavens. }\end{array}$ \\
\hline $\begin{array}{l}\text { Goldsmith } \\
\text { et al. }\end{array}$ & 2006 & 598 & USA & $\begin{array}{c}\text { Demographi } \\
\text { c }\end{array}$ & $\begin{array}{c}\text { There is no impact of } \\
\text { demographic } \\
\text { characteristics on defining } \\
\text { the market mavens. }\end{array}$ \\
\hline $\begin{array}{l}\text { Brancaleo } \\
\text { ne \& } \\
\text { Gountas }\end{array}$ & 2007 & 203 & $\begin{array}{l}\text { Austral } \\
\text { ia }\end{array}$ & $\begin{array}{c}\text { Demographi } \\
\text { c }\end{array}$ & $\begin{array}{c}\text { Income and education } \\
\text { levels of market mavens } \\
\text { are higher. } \\
\text { There is no difference } \\
\text { depending on gender. }\end{array}$ \\
\hline $\begin{array}{l}\text { Goodey\& } \\
\text { East }\end{array}$ & 2008 & 164 & $\underset{\mathrm{d}}{\text { Englan }}$ & $\begin{array}{l}\text { Demographi } \\
\text { c }\end{array}$ & $\begin{array}{c}\text { Women market mavens } \\
\text { are younger and less } \\
\text { educated compared to } \\
\text { men. }\end{array}$ \\
\hline Podoshen & 2008 & 332 & USA & $\begin{array}{c}\text { Demographi } \\
\text { c }\end{array}$ & $\begin{array}{c}\text { There is no difference } \\
\text { between afro-americans } \\
\text { and nonafro-americans } \\
\text { depending on market } \\
\text { mavenism. }\end{array}$ \\
\hline $\begin{array}{l}\text { Barnes\& } \\
\text { Pressey }\end{array}$ & 2012 & 342 & $\begin{array}{l}\text { Englan } \\
\mathrm{d}\end{array}$ & $\begin{array}{c}\text { Demographi } \\
\text { c }\end{array}$ & $\begin{array}{c}\text { Demographic } \\
\text { characteristics are not } \\
\text { among the determinants } \\
\text { of defining the market } \\
\text { mavens. }\end{array}$ \\
\hline $\begin{array}{l}\text { Goldsmith } \\
\text { et al. }\end{array}$ & 2012 & 258 & USA & Behavioral & $\begin{array}{c}\text { There are possitive } \\
\text { correlations between } \\
\text { market mavenism and } \\
\text { brand loyalty, } \\
\text { consumption and } \\
\text { materialism. }\end{array}$ \\
\hline Yang & 2013 & 835 & China & $\begin{array}{l}\text { Demographi } \\
\text { c } \\
\text { Psychologic }\end{array}$ & $\begin{array}{l}\text { Psychologic variables are } \\
\text { more distinctive } \\
\text { compared to demographic } \\
\text { characteristics. }\end{array}$ \\
\hline Puspa & 2014 & 134 & $\begin{array}{l}\text { Germa } \\
\text { ny }\end{array}$ & Behavioral & $\begin{array}{c}\text { There is no behavioral } \\
\text { differences between } \\
\text { low/middle/high level } \\
\text { market mavens. } \\
\text { High level market mavens } \\
\text { have less positive } \\
\text { attitudes compared to low } \\
\text { level market mavens } \\
\text { while it is statistically } \\
\text { insignificant. }\end{array}$ \\
\hline
\end{tabular}

Although there are different studies on market mavens; there is no consensus on the characteristics of the market mavens. But, there are some hints concerning the characteristics of the market mavens. Market mavens 
see price as an indicator of quality. Market mavens are consumers who are innovative and spend more time and money on shopping. (Goldsmith, Flynn and Goldsmith, 2003). There is a strong perception that there is a correlation between the price and the quality of a product. Because of market mavens' impressive character, ability to convey information to consumers, made them important in promotional activities compared to opinion leaders and innovators. But, when demographic characteristics are taken into consideration, market mavens have no differentiation characteristics as a target group. (Williams\&Slama, 1995). But, it is known that market mavens fill in more complaint questionnaires when compared to other consumers (Christiansen\&Tsiourtis, 1998).

Market mavens obtain information on products, stores and shopping by using various media channels and share this information with the consumers. (Price et.al, 1988) Market mavens became an important target market as they can affect consumers buying decisions. As they are active media users, it is easy to reach market mavens through ads and commercials. As the previous studies show, these are related with the characteristics of the market mavens and buying decisions (Williams\&Slama, 1995).

In addition to all these; when the characteristics of market mavens and non-mavens are analyzed there are three factors that are identified by Walsh et.al(2004). These are; responsibility of sharing information, happiness of sharing information and desire to help others. (Goodey\&East, 2008). According to the definition of the market maven; market mavens do not need to buy or use the product when it is offered to the market. Possessing and sharing general information about the market place is what differs them from opinion leaders and innovators. (Feick\&Price, 1987). Some characteristics of the market mavens can be defined as; high selfesteem, desire to be original, sensitivity to interpersonal communication. (Ruvio\&Shoham, 2007). In international literature, studies concerning market mavens are in variety but in national literature they are limited. As it is seen in Table 2 below: 
Table 2: National Literature on Market Mavens in Turkey

\begin{tabular}{|c|l|l|l|l|}
\hline Author(s) & Year & $\begin{array}{c}\text { Sample } \\
\text { Size }\end{array}$ & Dimension & Findings \\
\hline Yener & 2012 & 364 & Demographic & $\begin{array}{c}\text { Those who are 26-35 years of age and } \\
\text { women have tendency to become } \\
\text { market mavens. }\end{array}$ \\
\hline Yener & 2013 & 364 & Psychologic & $\begin{array}{c}\text { Market mavens have statistically } \\
\text { significant and positively greater } \\
\text { impact on reducing the perception of } \\
\text { risk. }\end{array}$ \\
\hline $\begin{array}{c}\text { Yolaç\& } \\
\text { Akyüz }\end{array}$ & 2014 & 372 & Demographic & $\begin{array}{c}\text { Women whose education and income } \\
\text { levels are higher have tendency to } \\
\text { become market mavens. } \\
\text { There is no correlation between } \\
\text { market mavenism level and } \\
\text { occupation/age/maritial status. }\end{array}$ \\
\hline $\begin{array}{c}\text { Ünal\& } \\
\text { Deveci }\end{array}$ & 2014 & 250 & Personal Traits & $\begin{array}{c}\text { Self-esteem, self-respect and } \\
\text { motivation variables are effective on } \\
\text { making a distinction between market } \\
\text { mavens and nonmavens. }\end{array}$ \\
\hline
\end{tabular}

When studies in Turkey are analyzed, it is seen that demographic and psychological characteristics of the market mavens are analyzed. But as it is also seen in international literature that there is no consensus on the general characteristics of market mavens.

In this study it is focused on the health mavens which are a special type of market mavens. Boster et.al (2011) defines health mavens as "are people who engage in information seeking behavior becoming experts in this case in health related topics”. But there are no studies following Boster et.al. (2011)'s pioneer study. In this pioneer study, data from 189 American people are obtained and concluded as "health mavens are individuals who can easily communicate with other people with a strong level of persuasiveness. There is no positive correlation with value-relevant involvement and no correlation with argumentativeness and social anxiety" In this study, it is aimed to define the demographic characteristics of the health mavens. In this respect, hints can be obtained pertaining to health mavens in order to be used in wider studies (In addition to this pioneering study, these two other studies can be taken into consideration on "influence" basis: Boster et.al. 2012 and Smith et.al. 2015).

\section{Aim and the Scale of the Research}

The aim of the research is to identify the demographic characteristics of the market mavens in health service sector. In this respect, likert type of scale developed by Feick\&Price (1987) (1= I strongly disagree 5= I strongly agree) is used. Besides, health maven scale developed by Boster et.al. (2011) is used. These scales are translated into Turkish by academics 
who work in the fields of English language and marketing. In order to prevent misunderstandings a double ended question is translated into two different questions and with the scale prepared 30 people are subjected to a preliminary study. As it is suggested in literature, consumers market mavenism scales can be classified as high, middle and low level. (Feick\& Price, 1987; Walsh et.al., 2004). With respect to this, Likert type of scale used in this research has a neutral degree of 3,00 and median levels below 3.00 is classified as "low" median levels between 3,01 and 3,99 are "middle", and median levels above 4 is classified as "high" health mavenism. Questions concerning the demographic characteristics like gender, education levels, marital status and income are closed ended questions where as age and occupation are open ended questions.

\section{Sample of the Research}

The research is carried out in Istanbul by using face to face survey technique. Consumers that are 18 and above are included in the scope of the research and convenience sampling method is used in reaching the consumers. The minimum sample size is calculated according to the most common formula (Kurtuluş, 2010: 67) given below depending on $5 \%$ error margin and $95 \%$ confidence interval:

$$
\begin{gathered}
\mathrm{n}=\pi(1-\pi) /(\mathrm{e} / \mathrm{Z})^{2} \\
\mathrm{n}=0,5 \mathrm{X} 0,5 /(0,05 / 1,96)^{2} \\
\mathrm{n}=384
\end{gathered}
$$

Out of 450 survey forms distributed to participants, 387 of them were added to the study after the elimination of the incomplete and erroneous forms.

\section{Findings}

People participated in the research are \%52,4 female, \%47,6 male; $\% 49,8$ single, \%50,2 married and \%35,9 18-28 aged, \%26,1 29-39 aged, $\% 22$ 40-50 aged and \%16 51 and above. As there are various answers to occupation section, this section is classified under employed, unemployed and students. Employed people form \%78,6, students \%13,1, unemployed $\% 8,3$ of the sample. Lower income group \%22,2, middle income group $\% 60,5$ and high income group \%17,3 are classified on monthly basis. Participants who have monthly income below or $1000 \mathrm{TL}$ are "low income group”,( \%22,2'), 1001-3000 TL (\%60,5) are middle income group 3001 $\mathrm{TL}(\% 17,3)$ and above are high income group. (Table 3 ) 
Table 3: Demographic Characteristics of the Sample Group

\begin{tabular}{|c|c|c|c|c|c|c|c|}
\hline & & $\begin{array}{c}\text { Frequen } \\
\text { cy }\end{array}$ & $\begin{array}{c}\text { Perce } \\
\text { nt }\end{array}$ & & & $\begin{array}{c}\text { Frequen } \\
\text { cy }\end{array}$ & $\begin{array}{c}\text { Perce } \\
\text { nt }\end{array}$ \\
\hline & $\begin{array}{c}\text { Femal } \\
\mathrm{e}\end{array}$ & 203 & $52,4 \%$ & & Primary School & 42 & $10,9 \%$ \\
\hline نัّ & Male & 184 & $48,6 \%$ & & High school & 90 & $23,3 \%$ \\
\hline . & Single & 193 & $49,8 \%$ & .气̊ำ & Associate degree & 99 & $25,5 \%$ \\
\hline$\sum 0$ & $\begin{array}{l}\text { Marri } \\
\text { ed }\end{array}$ & 194 & $50,2 \%$ & 포 & Undergraduate & 117 & $30,2 \%$ \\
\hline & $18-28$ & 139 & $35,9 \%$ & & Postgraduate & 30 & $7,8 \%$ \\
\hline & $29-39$ & 101 & $26,1 \%$ & & Phd & 9 & $2,3 \%$ \\
\hline$<$ & $40-50$ & 85 & $22,0 \%$ & & Low income group & 86 & אם כרי \\
\hline & $>51$ & 62 & $16,0 \%$ & & & & \\
\hline & Active & 304 & $78,6 \%$ & 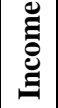 & $\begin{array}{l}\text { Medium income } \\
\text { group }\end{array}$ & 234 & $60.5 \%$ \\
\hline$\ddot{\Xi}$ & $\begin{array}{c}\text { Inacti } \\
\text { ve }\end{array}$ & 32 & $8,3 \%$ & 莺 & (1001-3000 TL) & & \\
\hline 旺 & $\begin{array}{c}\text { Stude } \\
\text { nt }\end{array}$ & 51 & $13,1 \%$ & & $\begin{array}{l}\text { High income group } \\
\text { (3001 TL and more) }\end{array}$ & 67 & $17,3 \%$ \\
\hline
\end{tabular}

The scale adapted for health mavenism by Feick\&Price (1987) and Boster, Franklin J., et al (2011) is also adapted for Turkey. This type of Likert scale which consists of six variables has a reliability analysis of 0,794 which is adequate for this research.

Table 4: Reliability Analysis Findings

\begin{tabular}{|c|c|}
\hline Items & Cronbach's Alpha \\
\hline 6 & 0,794 \\
\hline
\end{tabular}

As the median value of the answers of the scale shows health mavenism has three levels as low, middle and high.(Feick\&Price, 1987; Walsh vd, 2004). Out of 387 people of the sample, $188(\% 48,5)$ people have 
high, 97 people $(\% 25,1)$ have middle $102(\% 26,4)$ people have low levels of health mavenism. (see. Table 5)

Table 5: The Average Score of Health Mavens in the Survey

\begin{tabular}{|c|c|c|c|c|c|c|c|c|c|c|}
\hline \multirow{2}{*}{$\begin{array}{l}\text { Level of } \\
\text { Health } \\
\text { Mavenism }\end{array}$} & \multicolumn{9}{|c|}{ Average } & \multirow[b]{2}{*}{ Total } \\
\hline & 1,00 & 1,50 & 2,00 & 2,50 & 3,00 & 3,50 & 4,00 & 4,50 & 5,00 & \\
\hline $\begin{array}{c}\text { Low } \\
\text { Level }\end{array}$ & 3 & 4 & 9 & 26 & 60 & 0 & 0 & 0 & 0 & 102 \\
\hline $\begin{array}{l}\text { Middle } \\
\text { Level }\end{array}$ & 0 & 0 & 0 & 0 & 0 & 97 & 0 & 0 & 0 & 97 \\
\hline $\begin{array}{l}\text { High } \\
\text { Level }\end{array}$ & 0 & 0 & 0 & 0 & 0 & 0 & 90 & 55 & 43 & 188 \\
\hline TOTAL & 3 & 4 & 9 & 26 & 61 & 96 & 90 & 55 & 43 & 387 \\
\hline
\end{tabular}

The relationship between the level of health mavenism and demographic characteristics are tested by "Kendall's tau-b correlation analysis". According to the correlation analysis age, education level and marital status are determiner demographic characteristics of health mavens. But there is no statistically meaningful relationship between gender, occupation, income levels and health mavenism. (see Table 6)

Tablo 6 : Results of Kendall's tau_b correlation analysis

\begin{tabular}{|c|l|l|l|l|l|l|l|l|}
\hline & & & Age & Gender & Education & $\begin{array}{l}\text { Marital } \\
\text { status }\end{array}$ & Occupation & Income \\
\hline $\begin{array}{c}\text { Kendall's } \\
\text { tau_b }\end{array}$ & $\begin{array}{c}\text { Health } \\
\text { Maven }\end{array}$ & $\begin{array}{l}\text { Correlation } \\
\text { Coefficient }\end{array}$ &,$- 104^{*}$ &,- 067 &, $200^{* *}$ &,$- 113^{*}$ &,- 047 &, 061 \\
\cline { 2 - 9 } & $\begin{array}{c}\text { Sig. (2- } \\
\text { tailed) }\end{array}$ & $\mathbf{, 0 1 9}$ &, 167 & $\mathbf{, 0 0 0}$ & $\mathbf{, 0 1 9}$ &, 319 &, 164 \\
\cline { 2 - 9 } & $\mathrm{N}$ & 387 & 387 & 387 & 387 & 387 & 387 \\
\hline
\end{tabular}

As seen in Table 6, there is a weak relationship between age and health mavenism due to 0,104 correlation coefficient. So, it is possible to say that young consumers have more tendency to become health mavens. There is a 0,200 correlation coefficient between educational level and health mavenism. In this respect, it is possible to say that tendency to become health mavens rises with the education level. The last demographic variable that has statistically meaningful relationship with health mavenism is marital status. The correlation coefficient in this relationship is $-0,113$ which indicates that health mavens are mostly married.

\section{Conclusion}

W.O.M concentrates on interpersonal communication and is a field of study that is in the foreground in every sector of marketing. In this context, market mavens are attractive consumer groups for many academics due to their capability of obtaining and sharing information about the marketplace. As studies about market mavens in different sectors and product categories grow, the existence and activities of market mavens in health sector has 
become a current field of study. In this study, the existence and characteristics of health mavens are analyzed as a pilot study in Turkey.

The research carried out cannot produce generalized data due to its sampling method but it gives hints about health mavens. Out of 387 people in the sample \%75,6 have middle and high levels of health mavenism. The demographic characteristics such as age, education level and gender are meaningful variables in defining health mavens. Education has a positive correlation with health mavenism, others have negative correlation with health mavenism. In this respect, health mavens in this sample are educated young singles. On the other hand there is no statistically meaningful relationship between gender, occupation, income and health mavenism.

It is disadvantageous not to have a study to compare the findings but these findings as a pioneer pilot study show that producers of healthcare services when communicating with the receivers of these services, should keep in mind that health mavens are important channels of communication. Likewise; both academics and practitioners in the field should work on health mavens. Especially, in health sector where advertising restraints are intense, health mavens can have an important role in promotional activities.

Findings are important to show that the existence of health mavens. It is impossible to make generalizations with a pilot study but to define the characteristics of health mavens it opens the door for forthcoming studies. For forthcoming studies it is possible to include other cities in Turkey and use random sampling method. In literature, there is no consensus on market mavens characteristics, the same implications are also valid for health mavens. As Laughlin \&MacDonald (2010:57) state when demographic data do not provide enough information for practitioners who target health sector, it is important to have supplementary information besides demographic characteristics. In this respect forthcoming studies can provide data for psychological and behavioral characteristics of health mavens.

\section{References:}

Abratt, R., Nel, D., \& Nezer, C. (1995). Role of the market maven in retailing: A general marketplace influencer. Journal of Business and Psychology, 10(1), 31-55.

Aliye, Kayış (2005), "Güvenilirlik Analizi”, SPSS Uygulamalı Çok Değişkenli İstatistik Teknikler, (Ed. Şeref Kalaycı), 1.Baskı, Ankara, Asil Yayın Dağıtım, (404-419).

Barnes, S. J., \& Pressey, A. D. (2012). In Search of the "Meta-Maven": An Examination of Market Maven Behavior across Real-Life, Web, and Virtual World Marketing Channels. Psychology \& Marketing, 29(3), 167-185.

Boster, F. J., Kotowski, M. R., Andrews, K. R., \& Serota, K. (2011). Identifying influence: Development and validation of the connectivity, 
persuasiveness, and maven scales. Journal of Communication, 61(1), 178196.

Brancaleone, V., \& Gountas, J. (2007). Personality characteristics of market mavens. Advances in Consumer Research, 34, 522.

Chelminski, P., \& Coulter, R. (2002). Examining polish market mavens and their attitudes toward advertising. Journal of East-West Business, 8(1), 7790 .

Clark, R. A., \& Goldsmith, R. E. (2005). Market mavens: Psychological influences. Psychology \& Marketing, 22(4), 289-312.

Clark, R. A., Goldsmith, R. E., \& Goldsmith, E. B. (2008). Market mavenism and consumer self-confidence. Journal of Consumer Behaviour, 7(3), 239-248.

Çaylak, P., \& Tolon, M. (2014). Ağızdan Ağıza Pazarlama ve Tüketicilerin Ağızdan Ağıza Pazarlamayı Kullanımları Üzerine Bir Araştırma. İktisadi ve İdari Bilimler Fakültesi Dergisi, 15(3), 1-30. Feick, L. F., \& Price, L. L. (1987). The market maven: A diffuser of marketplace information. The Journal of Marketing, 83-97.

Geissler, G. L., \& Edison, S. W. (2005). Market mavens' attitudes towards general technology: Implications for marketing communications. Journal of Marketing Communications, 11(2), 73-94.

Goldsmith, R. E., Clark, R. A., \& Goldsmith, E. B. (2006). Extending the psychological profile of market mavenism. Journal of Consumer Behaviour,5(5), 411-419.

Goodey, C., \& East, R. (2008). Testing the market maven concept. Journal of Marketing Management, 24(3-4), 265-282.

Kontos, E. Z., Emmons, K. M., Puleo, E., \& Viswanath, K. (2011). Determinants and beliefs of health information mavens among a lowersocioeconomic position and minority population. Social Science \& Medicine,73(1), 22-32.

Öz, Murat, and Uyar, Esra. "Sağlık Hizmetleri Pazarlamasında Algılanan Hizmet Kalitesi ve Müşteri Memnuniyeti Üzerinde Ağızdan Ağıa Pazarlamanın Etkisini Belirlemeye Yönelik Bir Araştırma." (2014).

Price, L. L., Feick, L. F., \& Guskey-Federouch, A. (1988). Couponing behaviors of the market maven: profile of a super couponer. Advances in consumer research, 15(1), 354-359

Puspa, J. (2014). Economic Benefits and Reference Potential of Market Mavens. In 2014 AAEA/EAAE/CAES Joint Symposium: Social Networks, Social Media and the Economics of Food, May 29-30, 2014, Montreal, Canada(No. 166095). Agricultural and Applied Economics Association \& Canadian Agricultural Economics Society \& European Association of Agricultural Economists. 
Ruvio, Ayalla, Shoham Aviv, (2007), Innovativeness, Exploratory Behavior, Market Mavenship, and Opinion Leadership: An Empirical Examination in the Asian Context, Psychology \& Marketing, Vol. 24, No. 8, August, pp. 703-722.

Schumann, J. H., v. Wangenheim, F., Stringfellow, A., Yang, Z., Blazevic, V., Praxmarer, S., \& Jiménez, F. R. (2010). Cross-cultural differences in the effect of received word-of-mouth referral in relational service exchange. Journal of International Marketing, 18(3), 62-80.

Slama, M. E., \& Williams, T. G. (1990). Generalization of the market maven's information provision tendency across product categories. Advances in consumer research, 17(1), 48-52.

Uzunal, Beyza\&Mert UYDACI. "Sağlık kurumlarında ağızdan ağıza pazarlama ve bir pilot çalışma-word of mouth marketıng in health care organızatıons and a pilot study."Öneri Dergisi 9.34 (2012): 87-95.

Walsh, G., Gwinner, K. P., \& Swanson, S. R. (2004). What makes mavens tick? Exploring the motives of market mavens' initiation of information diffusion. Journal of Consumer Marketing, 21(2), 109-122.

Walsh, G., \& Elsner, R. (2012). Improving referral management by quantifying market mavens' word of mouth value. European Management Journal, 30(1), 74-81.

Williams, T. G., \& Slama, M. E. (1995). Market mavens' purchase decision evaluative criteria: implications for brand and store promotion efforts. Journal of Consumer Marketing, 12(3), 4-21.

Yener, D. (2012). Türkiye'deki Pazar Eksperlerinin Profil Özellikleri Ve Alışverişe Yönelik Tutumları. EJOVOC: Electronic Journal of Vocational Colleges, 2(2).

Y1lmaz, Eda. "Sağlik Hizmetlerinde Ağizdan Ağiza Pazarlama."Marmara Sosyal Araştırmalar Dergisi 1 (2011).

Yolaç, G., \& Akyüz, İ. (2015). Tüketici Kararlarında Etkin Bir Role Sahip Olan Pazar Kurtlarının Demographic Özellikleri Üzerine Bir İnceleme-An Investigation Of Demographics On Market Mavens' That Has An Effective Role On Consumer Decision Making. Mehmet Akif Ersoy Üniversitesi Sosyal Bilimler Enstitüsü Dergisi, 6(11), 133-143. 